\title{
Penetrating neck traumas
}

\author{
Mariusz Łochowski, Jacek Kaczmarski, Daniel Brzeziński, Bartosz Cieślik-Wolski, Józef Kozak
}

Department of Thoracic Surgery, Medical University of Lodz, Lodz, Poland

Kardiochirurgia i Torakochirurgia Polska 2014; 11 (1): 30-33

\begin{abstract}
Aim of the study is to present our own experiences in the treatment of people suffering from penetrating neck traumas.

Material and methods: In the years 1996-2012, 10 patients with penetrating neck traumas were treated, including 3 women and 7 men. The patients' age ranged from 16 to 55 (the average age being 40.7 years). In 9 cases the wound was caused by cutting or stabbing, while in one case it was inflicted by a gunshot. In 8 patients it was a single cut wound, while one patient suffered from 34 stab wounds to the neck, chest and stomach. Two cut wounds resulted from a suicide attempt. The remaining injuries were the result of a crime.

Results: All patients underwent immediate surgery, which involved revision of the neck wounds in 8 cases, one longitudinal sternotomy and one left-sided thoracotomy. The indications for surgery included increased subcutaneous emphysema in 5 patients, bleeding from the wound in 3 patients, and mediastinal hematoma in 2 patients. The damage assessed intraoperatively included tracheal damage in 6 patients, damage to carotid vessels in 3 patients, larynx in 2 patients, thoracic vessels in 2 patients, oesophagus in 1 patient and thyroid gland in 1 patient. In 9 patients, the treatment yielded positive results. The patient with a gunshot wound died during the surgery due to massive bleeding from the aorta.

Conclusions: In patients with penetrating neck wounds, early and rapid diagnostics allows one to determine the indications for surgery and prevent serious fatal complications.

Key words: penetrating neck traumas, stab wounds, gunshot wounds, revision of neck wounds, subcutaneous emphysema, mediastinal hematoma.
\end{abstract}

\section{Introduction}

The first descriptions of the treatment of penetrating neck wounds come from 1522, when Ambroise Paré described the technique of tying large vessels at the site of injury. Those principles were later used during World War I. Mortality from neck wounds was evaluated at $60 \%$ at that time.

\section{Streszczenie}

Celem pracy jest przedstawienie własnych doświadczeń w leczeniu penetrujących urazów szyi.

Materiat i metody: W latach 1996-2012 leczeniu poddano 10 pacjentów z penetrującymi urazami szyi, w tym 3 kobiety i 7 mężczyzn. Wiek pacjentów wynosił 16-55 lat (średnia wieku: 40,7 roku). W 9 przypadkach stwierdzono rany kłute, w jednym przypadku ranę spowodowaną postrzałem. W 8 przypadkach była to pojedyncza rana kłuta, a w przypadku jednego pacjenta - 34 rany kłute szyi, klatki piersiowej i brzucha. Dwie rany były wynikiem próby samobójczej, pozostałe wynikiem przestępstwa.

Wyniki: Wszystkich pacjentów poddano natychmiastowemu zabiegowi polegającemu na rewizji ran szyi (8 przypadków), sternotomii z podłużnym przecięciem mostka (1 przypadek) oraz lewostronnej torakotomii (1 przypadek). Wskazania do zabiegu obejmowały rozedmę podskórną (5 pacjentów), krwawienie z rany (3 pacjentów) i hematomę śródpiersia (2 pacjentów). Wśród urazów stwierdzonych śródoperacyjnie były uszkodzenia tchawicy (6 pacjentów), tętnic szyjnych (3 pacjentów), krtani (2 pacjentów), naczyń klatki piersiowej (2 pacjentów), przełyku (1 pacjent) i gruczołu tarczowego (1 pacjent). W przypadku 9 pacjentów leczenie przyniosło pozytywne efekty. Pacjent z raną postrzałową zmarł podczas zabiegu wskutek obfitego krwawienia z aorty.

Wnioski: Wczesna i szybka diagnostyka u pacjentów z penetrującymi ranami szyi pozwala określić wskazania do zabiegu i zapobiec śmiertelnym powikłaniom.

Słowa kluczowe: urazy penetrujące szyi, rany kłute, rany postrzałowe, rewizja ran szyi, rozedma podskórna, hematoma śródpiersia.

During World War II, the mandatory reviewing of all penetrating neck wounds was recommended. The mortality rate dropped to $6 \%$ in early wound reviewing, in comparison to $35 \%$ in cases of delays in treatment $[1,2]$. In this paper we intend to present our own experience in conducting diagnostics and treatment of penetrating neck traumas. 


\section{Material and methods}

From 1996 to 2012, 10 patients with penetrating neck traumas were treated, including 3 females and 7 males. The age of the patients ranged from 16 to 55 (the average age being 40.7 years). In 9 cases, wounds were inflicted with a knife ( 7 cut wounds, 2 stab wounds), and in 1 case it was a gunshot wound. Knife wounds were single in 8 patients and multiple (34 stab wounds) in 1 patient, including wounds to the chest and stomach. In 2 patients, injuries were due to suicide attempts, while the remaining ones resulted from crimes.

According to the criteria laid down by Rono and Christiansen, the neck is divided into three zones. Zone I extends between the zygomatic cleft of the sternum and the lower edge of the cricoid cartilage. Zone II is the area between the lower edge of the cricoid cartilage and the line connecting both angles of the jaw. The area located above this line is zone III of the neck. In our material, the injuries concerned mostly zone I (8 patients). In 2 cases, the injury involved zone II. We did not observe injuries in zone III of the neck. The only gunshot wound in the material was in zone I.

Among the observed symptoms, subcutaneous emphysema (in 5 cases) and bleeding from a wound (in 3 cases) were predominant. The patients' characteristics are presented in Table I.

The time from receiving the injury to diagnosis ranged from 1 to 8 hours (the average being 2.5 hours). In 5 patients, the diagnosis was based on the clinical picture and bronchoscopy examination. Three patients with bleeding from the wound were operated on immediately. In 2 patients, the final diagnosis was based on computed tomography of the chest, revealing an upper mediastinal haematoma in one patient and a mediastinal haematoma with an associated left pleural haematoma in the other one.

Tab. I. Characteristics of patients with penetrating neck trauma

\begin{tabular}{|c|c|c|c|c|c|c|c|}
\hline No. & Sex & Age & Cause & $\begin{array}{l}\text { Time from the trauma } \\
\text { [hours] }\end{array}$ & Neck zone & Symptoms & $\begin{array}{l}\text { Lab. test } \\
\mathrm{Hb}[\mathrm{g} / \mathrm{dl}]\end{array}$ \\
\hline 1. & M & 52 & Cut wound & 1 & I & Bleeding & 11.3 \\
\hline 2. & M & 48 & Cut wound & 1 & I & Subcutaneous emphysema & 13.2 \\
\hline 3. & M & 46 & Cut wound & 1 & $\|$ & Bleeding & 10.7 \\
\hline 4. & $\mathrm{~F}$ & 26 & Cut wound & 8 & I & Subcutaneous emphysema & 12.7 \\
\hline 5. & $\mathrm{~F}$ & 40 & Cut wound & 4 & I & Subcutaneous emphysema & 11.9 \\
\hline 6. & M & 55 & Cut wound & 1 & I & Bleeding & 11.0 \\
\hline 7. & M & 50 & $\begin{array}{l}34 \text { stab } \\
\text { wounds: } \\
\text { neck, chest, } \\
\text { stomach }\end{array}$ & 2 & I & $\begin{array}{l}\text { Subcutaneous emphysema } \\
\text { Pneumothorax } \\
\text { Neck haematoma }\end{array}$ & 9.3 \\
\hline 8. & M & 16 & Stab wound & 3 & I & Mediastinal haematoma & 9.4 \\
\hline 9. & M & 42 & Cut wound & 2 & $\|$ & Subcutaneous emphysema & 13.1 \\
\hline 10 & $\mathrm{~F}$ & 34 & $\begin{array}{l}\text { Gunshot } \\
\text { wound }\end{array}$ & 4 & I & $\begin{array}{l}\text { Mediastinal haematoma and left } \\
\text { haemothorax }\end{array}$ & 6.8 \\
\hline
\end{tabular}

\section{Results}

All patients underwent surgery. Indications for surgery included increasing subcutaneous emphysema in 5 patients, bleeding from the wound in 3 patients, and mediastinal haematoma in 2 patients. Intraoperatively, tracheal 3 patients, laryngeal injury in 2 patients, thoracic vessel injury in 2 patients, oesophageal injury in 1 patient, and thyroid gland injury in 1 patient. A surgical access through the revision of the wound trauma was performed in $8 \mathrm{ca}$ ses. In 1 case, a longitudinal sternotomy and, in another case, a left-sided thoracotomy were performed (Table II). The damaged larynx and trachea were supplied with single stitches and the oesophagus received two layers. The area of the stitches was covered with surrounding tissues. In the patient with the mediastinal haematoma, a median sternotomy was performed, revealing the damage of the brachial-cranial stem. The brachial-cranial stem was supplied with a vascular stitch. The patient with the gunshot wound, suffering from mediastinal haematoma and left pleural haematoma, was opened through left-sided thoracotomy. Massive bleeding from the disrupted aorta was found, which could not be dressed.

In 9 patients, good treatment results were obtained. The patient with the gunshot wound died. Follow-up bronchoscopy did not show any changes in the place of tracheal sewing. The oesophageal wound healed well. In no case did bleeding from neck vessels lead to an ischaemic cerebral stroke. Patients after suicide attempts were referred for psychiatric treatment. The duration of hospitalization ranged from 7 to 14 days.

\section{Discussion}

Penetrating neck wounds account for about $5-10 \%$ of all patients admitted due to injuries. The complicated anainjury was found in 6 patients, carotid vessel injury in 
Tab. II. Treatment of patients with penetrating neck trauma

\begin{tabular}{llllll} 
No. & Sex & Age & Surgical approach & Type of injury & $\begin{array}{c}\text { Hospitalization } \\
\text { time }\end{array}$ \\
1. & $M$ & 52 & Revision of the wound & Tracheal and carotid vessels injury & 10 \\
\hline 2. & $M$ & 48 & Revision of the wound & Tracheal and thyroid gland injury & 11 \\
\hline 3. & M & 46 & Revision of the wound & Laryngeal injury & 7 \\
\hline 4. & F & 26 & Revision of the wound & Tracheal injury & 7 \\
\hline 5. & F & 40 & Revision of the wound & Tracheal injury & 8 \\
\hline 6. & $M$ & 55 & Revision of the wound & Tracheal and carotid vessels injury & 10 \\
\hline 7. & $M$ & 50 & Revision of the wound & Tracheal, carotid vessels and oesophageal injury & 14 \\
\hline 8. & $M$ & 16 & Longitudinal sternotomy & Damage to the brachial-cranial stem & 9 \\
\hline 9. & M & 42 & Revision of the wound & Laryngeal injury & 8 \\
\hline 10. & F & 34 & Left thoracotomy & Disrupted aorta & Death
\end{tabular}

tomy of the neck and the location of very important vital structures on a small surface make the evaluation of damage and indications for surgical intervention difficult $[3,4]$. The gravity of the problem is increased even more by the fact that the mortality from injuries to this area may reach as much as $11 \%[1,4]$. Mortality depends on the neck zone exposed to injury and the type of tool inflicting the injury $[4,5]$. Mortality from penetrating neck trauma in zone I is estimated at $12.1 \%$, in zone $\mathrm{II}$ at $7 \%$, and in zone III at $8 \%$ [3, $6,7]$. Table III presents data of various authors illustrating the relationship between mortality and type of tool (guns, sharp tools) used by the person inflicting the wound. The table shows the significantly higher mortality rate of gunshot wounds compared to stab wounds. There is a particularly high mortality rate for gunshot wounds of zone I of the neck [4]. In our material such a case resulted in death.

In the study presented by Nason et al. [4] and carried out on 134 patients, $95 \%$ of the patients had stab wounds and only $5 \%$ had gunshot wounds. A similar relationship could be observed in our material. The data on crime are completely opposite in the USA, where the percentage of neck gunshots was as high as 50\% [4]. Victims of penetrating neck trauma suffer serious life-threatening damage to the structures running there. McConnell and Trunkey [8] emphasize the higher incidence of respiratory and digestive tract injures compared to those of vascular and nerve structures in penetrating neck trauma. A similar picture can be observed in our material. Moreover, our patients suffered mostly from injuries of the larynx and trachea.

An important factor determining the patient's survival is his fast transport to the hospital. It is estimated that about $30-80 \%$ of patients with respiratory tract injuries die during transport to the hospital [9]. The main symptoms of respiratory tract damage in neck injuries include subcutaneous emphysema and respiratory failure requiring intubation of the patient and ventilation replacement already during transport to the hospital $[9,10]$.

Based on 10 years of research, Argood et al. [10] determined factors that may influence complications in patients with injuries to the larynx and the neck part of the trachea. They include:

1) delay in diagnosis,

2) type of neck injuries,

3) presence of other associated damage.

The "gold standard" in the diagnosis of injuries of the respiratory tract is bronchoscopy. Bronchoscopy allows one to evaluate the location and extent of the damaged area $[9,11]$. Argood et al. [10] believe that the common use of bronchoscopy enables the prevention of delay in diagnosis and avoidance of treatment failures. In half of our patients, we performed bronchoscopy revealing damage to the respiratory tract.

Tab. III. Mortality in stab and gunshot wounds of the neck in reports of various authors [5]

\begin{tabular}{lcccc} 
Author & Number of patients & Overall mortality & Mortality from stab wounds & Mortality from gunshot wounds \\
Ordog & 276 & $1.2 \%$ & $0 \%$ & $2.2 \%$ \\
\hline Elderling & 75 & $5 \%$ & $0 \%$ & $12 \%$ \\
\hline Knightly & 116 & $3.5 \%$ & $4.2 \%$ & $8.8 \%$ \\
\hline Sheely & 632 & $5.5 \%$ & $2.1 \%$ & $6.6 \%$ \\
\hline Roon & 189 & $2.6 \%$ & $4.1 \%$ \\
\hline
\end{tabular}




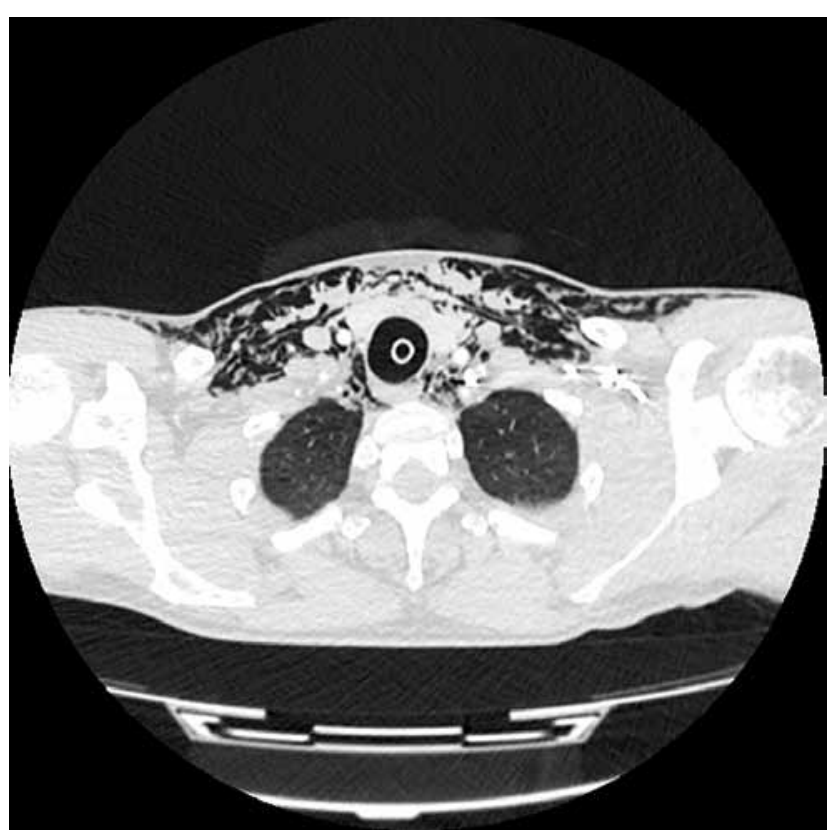

Fig. 1. Woman, 26 year, with tracheal injury. Subcutaneous and upper mediastinal emphysema

Indications for surgical interventions in neck injuries include [3]:

1) active bleeding, haematoma or haemorrhagic shock,

2) presence of blood in the respiratory and digestive tracts,

3) respiratory failure, subcutaneous emphysema,

4) neurological symptoms.

In our patients, increasing subcutaneous emphysema was the main indication for performing surgery (Fig. 1). Mediastinal bleeding and haemothorax constituted the other half of the indications (Fig. 2).

Until recently, in many centres, the review of all penetrating neck traumas was considered mandatory. Supporters of this tactic put forward an argument of the high risk of omission or delay in diagnosing patients, which may have fatal consequences. Opponents of the selective observation of patients put forward an argument of the high percentage of negative neck revisions - 30-89\% [4, 7, 12, 13]. All of our patients were operated on. The time between the trauma and the diagnosis was approx. 2.5 hours. We think that a surgical intervention is required only in those patients who meet the indications. Other patients require a careful diagnosis during a 24-hour observation.

\section{Conclusions}

Based on the acquired experience, we believe that an early and fast diagnosis can determine indications for surgery and prevent severe fatal complications.

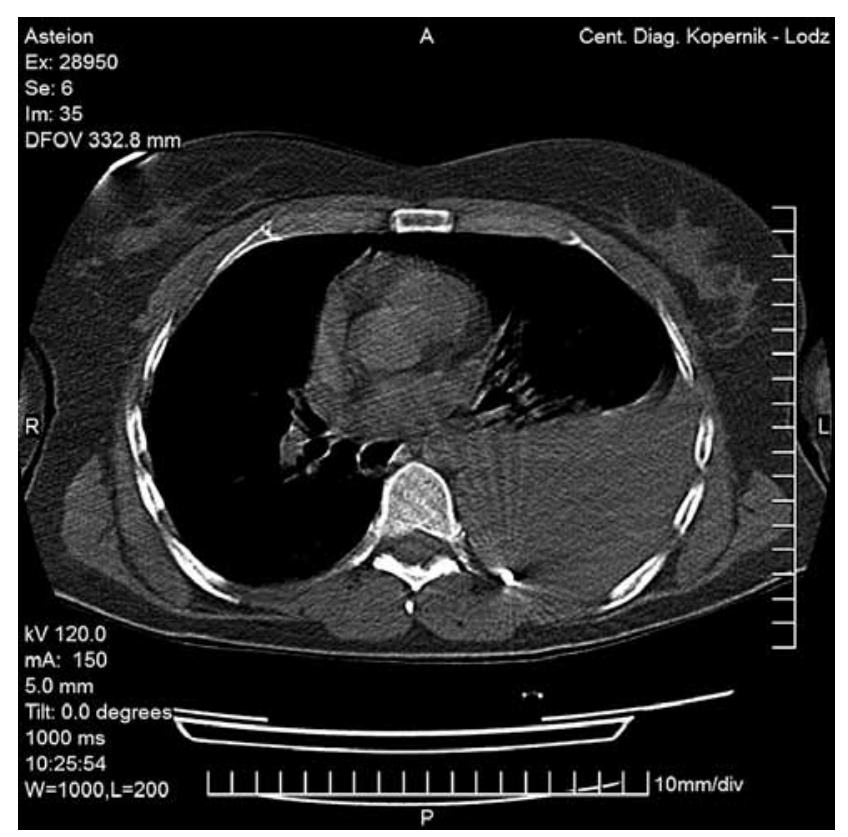

Fig. 2. Woman, 34 year, with disrupted aorta. Left hemothorax and shot in the pleural cavity

\section{References}

1. Dr. Quinn's Online Textbook of Otolaryngology: Penetrating neck trauma. Grand Rounds Archive 1995.

2. Jarvik JG, Philips GR 3rd, Schwab CW, Schwartz JS, Grossman RI. Penetrating neck trauma. AJNR Am J Neuroradiol 1995; 16: 647-654.

3. Rao PM, Khan Bhatti MF, Gaudino J, Ivatury RR, Aquarwal N, Nallathambi MN, Stahl WM. Penetrating injures of the neck: criteria for exploration. J Trauma 1983; 23: 47-49.

4. Nason RW, Assuras GN, Gray PR, Lipschitz J, Burns CM. Penetrating neck injuries: analysis of experience from a Canadian trauma centre. Can J Surg 2001; 44: 122-126.

5. Ordog GJ. Penetrating neck trauma. J Trauma 1987; 27: 543-554.

6. Sclafani SJA, Panetta T, Goldstein AC. The management of arterial injures caused by penetration of zone III of the neck. J Trauma 1985; 25: 871-881.

7. Meyer JP, Barrett JA, Schuler JJ. Mandatory vs selective exploration for penetrating neck trauma. Arch Surg 1987; 122: 592-597.

8. McConnell DB, Trunkey DD. Management of penetrating trauma of the neck. Adv Surg 1994; 71: 97-127.

9. Andres AG-C, Herrero PA, Diez FJM. Medical and surgical management of nonidiopathic traumatic tracheobronchial injures. Arch Bronconeumol 2005; 41: 249-254.

10. Argood PB, Attia EL, Brown RA, Muldes DS. Extrinsic civilian trauma to the larynx and cervical trachea - important predictors of long term morbidity. J Trauma 1986; 26: 869-873.

11. Hara KS, Prakash UB. Fiberoptic bronchoscopy in the evaluation of acute chest and upper airway trauma. Chest 1989; 96: 627-630.

12. Wood J, Fabian TC, Mangiante EC. Penetrating neck injuries: recommendations for selective management. J Trauma 1989; 29: 602-605.

13. Łochowski M, Kozak J. Rany kłute dołka jarzmowego szyi. Pol Przegl Chir 1999; 71: 74-77. 